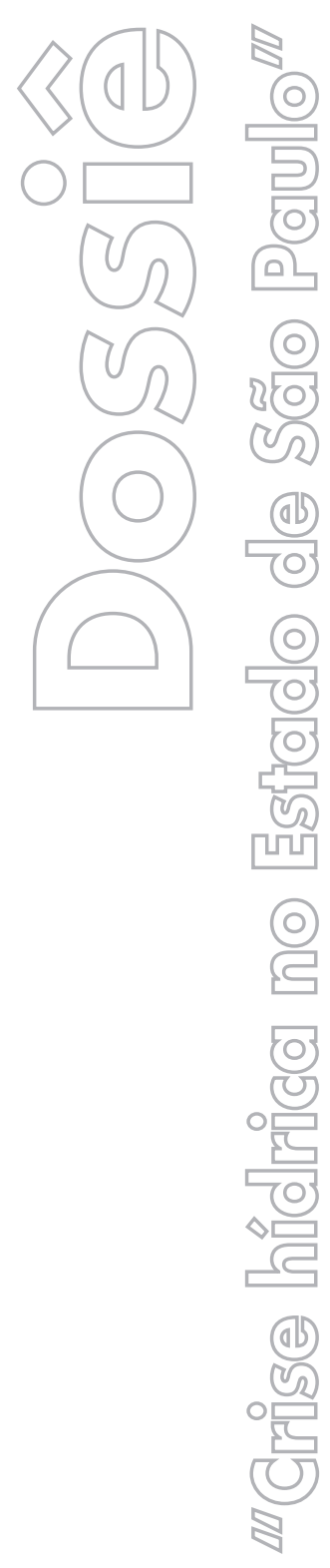

revista

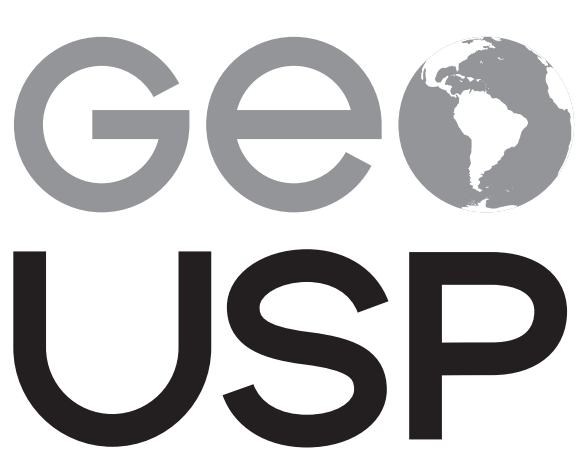

espaço e tempo

Volume $19 \cdot n^{\circ} 3$ (2015)
Disponibilidade e escassez de água na grande São Paulo: elementos-chave para compreender a origem da atual crise de abastecimento

\author{
Cleide Rodrigues \\ USP
}

Fernando Nadal Junqueira Villela

USP

p. $399-421$

Como citar este artigo:

RODRIGUES, C.; VILLELA, F. N. J. Disponibilidade e escassez de água na Grande São Paulo: elementos-chave para compreender a origem da atual crise de abastecimento. Geousp - Espaço e Tempo (Online), v. 19, n. 3, p. 399-421, mês. 2016. ISSN 2179-0892.

Disponível em: URL: http://www.revistas.usp.br/ geousp/article/view/111496/112845. DOI: http://dx.doi. org/10.11606/issn.2179-0892.geousp.2015.111496.

\section{(c) $(1)$ (9)}

Este artigo está licenciado sob a Creative Commons Attribution 4.0 License. 


\title{
Disponibilidade e escassez de água na grande São Paulo: elementos-chave para compreender a origem da atual crise de abastecimento
}

\section{Resumo}

Este estudo identifica elementos e recortes temporoespaciais para sugerir aprofundamentos na abordagem das causas da atual crise de abastecimento de água na região da Grande São Paulo. Consideram-se questões climáticas, a mídia impressa e suas ênfases, além da questão dos marcos regulatórios, evolução da capacidade instalada para o abastecimento da região e as condições de conservação da área produtora de água bruta do Sistema Cantareira. Esta avaliação é fundamentada em estudos de especialistas e pesquisas desenvolvidas no âmbito da hidrografia e geografia nas bacias hidrográficas geradoras, cujos dados são utilizados para avaliar a gestão dos recursos hídricos de longo prazo no âmbito da responsabilidade governamental. Faz-se também uma breve análise da variabilidade das chuvas que, em conjunto com os demais elementos apresentados, demonstra ser necessário conjugar uma série de fatores para compreender a crise hídrica atual.

Palavras-chave: Sistema Cantareira. Mídia impressa. Questões climáticas. Grande São Paulo. Crise hídrica.

\section{Availability and water shortages in Greater São Paulo: key elements to understand the origin of the current supply crisis}

\begin{abstract}
This study identifies elements and establishes space-time cross sections in order to suggest deeper approaches into the causes of the present crisis in water supply in the Greater São Paulo region. We consider climatic questions, printed media and its focuses, besides the question of regulatory benchmarks, evolution of installed capacity for supplying the region and conservation of the bulk producing area of the Cantareira System. This evaluation is based on expert's studies and research developed within the range of Hydrography and Geography in the generating hydrographic basins, whose data are used to evaluate long-term ma-
\end{abstract}


nagement of the hydric resources within the area of governmental responsibility. We carry out also a brief analysis of rainfall variability which, together with the remaining elements presented herewith, demonstrate that it is necessary to combine a series of factors for the understanding of the current hydric crisis.

Keywords: Cantareira System. Printed media. Climatic questions. Greater São Paulo. Hydric crisis.

\section{Crise hídrica ou crise de abastecimento?}

Tratando-se da Grande São Paulo (GSP) e de problemas relativos à água, o desenvolvimento de leituras geográficas sobre o território permite afirmar que desde algumas décadas atrás já estaríamos diante de agudas e diversas "crises hídricas".

A cada tipo de valorização do território, processo altamente cambiante, principalmente no decorrer da história recente, correspondem diversas expectativas sobre a espacialidade, a dinâmica, a qualidade e a quantidade de água, em diversas escalas. Dessa diversidade de expectativas decorrem, por vezes, gestões, apropriações e manejos territoriais contraditórios, guiados fundamentalmente por agentes sociais e forças políticas de maior hegemonia.

Quanto à dinâmica e à espacialidade das águas de superfície, por exemplo, é preciso considerar que a maior parte das apropriações e funcionalidades urbanas requisitam a boa drenagem das superfícies, ou seja, demandam que a água ali não permaneça ou circule, o que explicaria, em parte, o grande foco em construção de estruturas hidráulicas com a função constringir a drenagem natural. Diversas apropriações espaciais e a própria economia urbana, beneficiam-se da drenagem artificial das águas de superfície, em sua maior parte confinadas a canais artificiais com uma ampliação média sete vezes acima das vazões máximas originais dos rios. Na medida em que impermeabilizações e estruturas de hidráulicas de drenagem urbana foram produzidas, também foram criados outros processos indesejáveis, como os de aumento de velocidade dos fluxos hídricos superficiais e de sua concentração espacial, ou, ainda, o alagamento em pontos específicos, criando-se novas situações de risco (Rodrigues, 2004, 2010, 2015). Os riscos ligados à circulação hídrica no meio urbano é outra questão que pode ser considerada crítica e ligada à água, sendo uma das múltiplas crises hídricas da Região Metropolitana de São Paulo (RMSP).

Por outro lado, se avaliada a questão da qualidade de água, a demanda por melhorias em seus índices seja para eventual consumo humano, vida aquática ou funções sanitárias, outra "crise da água" é rapidamente configurada.

É certo que todos esses problemas e, entre eles, o da atual crise de abastecimento, demandam soluções articuladas, complexas e custosas, de difícil implementação devido a uma dívida histórica das gestões em todos os aspectos citados e também em função da fragmentação de natureza político-administrativa e de políticas territoriais. Estamos, portanto, há décadas, diante de uma série de crises ligadas à água na RGSP, que vão, da crise sanitária ligada à saúde, à questão dos riscos como enxurradas e enchentes também ligados à mobilidade urbana, à falta de áreas públicas e de lazer e à própria disponibilidade de água, entre outras, todas elas envolvendo a dinâmica, a quantidade e a qualidade. 
Dessa forma, a atual crise se configura mais como uma faceta dessa crise geral, com um tipo específico de valorização do território, que é o da disponibilidade da água bruta (envolvendo clima, bacias geradoras sistemas de captação e reserva, tratamento e distribuição) e do consumo de água, a que chamaremos aqui de "crise de abastecimento".

Essas diversas crises da água e a dimensão de suas respectivas gravidades são analisáveis quando se aplicam parâmetros e critérios comumente presentes nos campos que compõem a geografia e a geografia física e estas são caracterizadas por abordagens, categorias, sistematizações e recortes espaciais que viabilizam articulação desses parâmetros, auxiliando na identificação de responsabilidades de agentes sociais. Exemplos de uso desses parâmetros e categorias são as avaliações produzidas a partir dos sistemas fluviais implicados na geração e consumo de água. $\bigcirc$ uso dessas categorias também viabiliza avaliações do grau de comprometimento desses sistemas quanto a sua degradação ou preservação ou ainda quanto à supressão de serviços ambientais e recursos naturais ao longo do tempo e até mesmo o grau de eficiência de obras hidráulicas, entre outras (Rodrigues, 2010, 2015).

Para a seleção dos pontos a serem focalizados na análise da crise de abastecimento à luz de categorias geográficas, foi inicialmente realizada uma avaliação dos elementos mais relevantes e pouco tratados pela mídia impressa, identificando-se as principais lacunas quanto ao tratamento de possíveis causas. A partir dessas lacunas de tratamento identificadas nesse âmbito, elegeram-se os elementos e foi dado a eles tratamento instrumental. Foram relevados outros possíveis nexos quanto à origem da crise e foram criadas bases para se instruir novos aprofundamentos a respeito das responsabilidades da gestão na geração da crise.

\section{A mídia impressa e suas ênfases}

É correto supor que, para formar um quadro fiel e detalhado do tratamento geral da mídia a respeito da crise de abastecimento, em seu pleno anúncio e curso, não bastaria considerar um único jornal ou um único tipo de veículo. Contudo, e apenas no sentido de identificar as principais lacunas de tratamento e aprofundamento, selecionou-se o período de julho de 2014 a janeiro de 2015 do jornal Folha de S.Paulo, com manchetes relativas à questão hídrica chamadas na primeira página, no primeiro caderno ou no caderno Cotidiano. Do ponto de vista da seleção do jornal, isso se justificou não só por se alcance nacional, com aproximadamente um milhão de leitores, mas principalmente por se haver adotado como premissa o entendimento de que esse jornal específico seja, na atualidade, um dos mais relevantes na formação e consolidação de opiniões hegemônicas da mídia brasileira em geral. Quanto ao intervalo temporal analisado, selecionou-se um intervalo amostral do período em que os jornais de maior alcance e a mídia em geral passam a tratar a questão do abastecimento de água na metrópole explicitamente como crise ou problema grave, o que acontece principalmente no segundo semestre de 2014 .

Sendo assim, foram analisadas 341 matérias que, em seu título, faziam menção ao abastecimento na Grande São Paulo. As matérias eram acessadas a partir de seu título, alternativa ou simultaneamente na primeira página, no editorial e no caderno Cotidiano. Essas matérias foram todas analisadas e classificadas nos seguintes tópicos principais: (1) gestão e caracterização da atual crise hídrica de abastecimento e (2) causas da atual crise hídrica de abastecimento. 
A partir da consideração dessas principais classes, definiram-se as seguintes subclasses: (1.a) nível dos reservatórios e condições do tempo, (1.b) medidas governamentais de pequeno porte/multas/restrições/rodízio, (1.c) obras emergenciais de maior porte, (1.d) iniciativas individuais ou locais/desperdício, (1.e) outras, (2.a) climáticas/devastação/natureza/extremos, (2.b) governo estadual/Alckmin/Sabesp, (2.c) debates amplos/opiniões divergentes/planejamento preventivo, (2.d) outras. Nas matérias em que os assuntos itemizados eram tratados simultaneamente, foi selecionado o mais relevante em termos de chamada/título ou espaço a ele dedicado no texto.

Os resultados trazem evidências inequívocas de tendências numéricas, tanto em relação aos assuntos efetivamente contemplados, como em assuntos relevantes ausentes ou pouco tratados, características essas que assumem contornos de caráter opinativo do jornal, mesmo diante do abrigo de opiniões contrárias.

Quanto à seleção dos assuntos, das 341 matérias jornalísticas analisadas, 81,2\% tratavam essencialmente do item gestão/caracterização da crise já instaurada e apenas 18,8\% tratavam de suas causas, assunto tão ou mais relevante que o primeiro, de onde se podem efetivamente tirar lições para evitar futuros erros (Tabela 1).

\section{Tabela 1 - Classificação temática de matérias jornalísticas sobre a crise hídrica de abastecimento da RMSP (dez. 2014/abr. 2015)}

\begin{tabular}{|c|c|c|c|}
\hline $\begin{array}{l}\text { tema das ma- } \\
\text { térias }\end{array}$ & no $-\%$ & subtemas & no $-\%$ \\
\hline \multirow{5}{*}{ 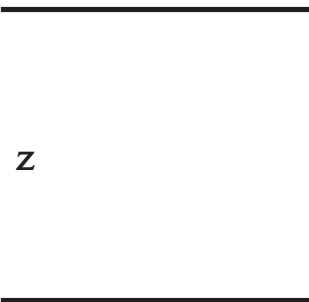 } & \multirow{3}{*}{277} & nível dos reservatórios: choveu/não choveu & $49-14,4 \%$ \\
\hline & & medidas governamentais; restrições & $62-18,2 \%$ \\
\hline & & obras emergenciais & $33-9,7 \%$ \\
\hline & \multirow[t]{2}{*}{$81,2 \%$} & iniciativas individuais/locais/efeitos & $87-25,5 \%$ \\
\hline & & outras (pontuais) & $46-13,5 \%$ \\
\hline \multirow{4}{*}{ causas da crise } & \multirow{2}{*}{64} & clima/devastação/natureza & $30-8,8 \%$ \\
\hline & & governo estadual/Sabesp & $29-8,5 \%$ \\
\hline & \multirow{2}{*}{$18,8 \%$} & matérias amplas/especialistas/históricas & $2-0,6 \%$ \\
\hline & & outras & $3-0,9 \%$ \\
\hline total & 341 & & \\
\hline
\end{tabular}

fonte: Folha de S.Paulo (2014/2015).

Quanto à gestão da própria crise e sua caracterização, foram identificadas 277 matérias, correspondendo a $81,3 \%$. Nessas matérias, os assuntos mais frequentes foram os que tratavam de iniciativas individuais, locais, ou efeitos da crise em bairros ou localidades específicas, tais como questões de desperdício (25,5\%). Em segundo lugar, aparecem as que trataram especialmente de medidas governamentais emergenciais, como diminuição da pressão (expressão pré-eleitoral) ou rodízio, com 18,2\%. Em terceiro lugar, aparecem as que se restringiram a informar o nível dos reservatórios e apresentar determinadas características do tempo no dia anterior $(14,4 \%)$ e, em quarto, as que tratavam das obras emergenciais (9,7\%). 
Quanto ao tratamento da origem da crise, mesmo conhecendo o esperado tratamento minoritário dado a esse item, em função de que demanda análises mais aprofundadas, chama atenção o quanto é menor (18,8\%). Também chamam atenção as causas que aparecem como mais frequentes: 8,8\% relativas ao clima (extremos, imprevisibilidade) e 15\%, a questões de gestão estadual.

Esse quadro revela uma avaliação do problema que pouco explora outras matrizes de explicativas. São lacunas evidentes as ligadas às causas da crise, principalmente no que se refere à gestão governamental e suas atribuições de planejamento preventivo e de longo prazo: como exemplo, têm-se as iniciativas de conservação das áreas ou bacias geradoras de água bruta e os investimentos em obras de caráter preventivo. Fazem parte dessa última, principalmente: obras voltadas à ampliação da capacidade de armazenamento, à diminuição de perdas e à interligação dos sistemas. Todas essas obras seriam emergenciais há pelo menos mais de duas décadas, tendo em vista os esperados eventos extremos proclamados pela agenda científica internacional, conforme tratado adiante.

Outro ponto que poderia ter sido mais bem explorado no período são as diversas opiniões quanto à matriz explicativa "clima e sua imprevisibilidade". Parte do tratamento dado na matriz explicativa climática induz a pensar que pouco poderia ter sido feito em termos de planejamento preventivo, devido à imprevisibilidade climática, e é justamente por essas ausências que também se trazem e analisam outros elementos.

A presença de algumas matérias de caráter amplo, nas quais especialistas em clima e em hidrologia aparecem com opiniões diversas, configura pluralidade ao jornal. Contudo, no período analisado, essas matérias acabam por reforçar a ideia de que a principal causa seria a de que essa "seca" ou "estiagem severa" tenha sido a mais aguda observada dos últimos 80 anos. Dentro dessa premissa também se quer ponderar aqui, em complementação e na mesma linha de estudos como os de Zuffo (2015) e Côrtes e Torrente (2015).

Em análise complementar, foram identificadas matérias amplas para todo o ano de 2014 onde identificaram-se algumas exceções quanto a essas tendências apontadas. São elas: a matéria a respeito do maior crescimento do consumo em relação à produção de água na RMSP, veiculada em 3 de abril de 2014, e a matéria de 8 de agosto de 2014, em que Catarina de Albuquerque, relatora da $\mathrm{ONU}$, reitera que a responsabilidade pela crise seria mesmo do governo estadual, chegando a afirmar que foram violados direitos humanos. Alguns posicionamentos do jornal em editorial, já no período analisado (julho de 2014 a janeiro de 2015), reforçaram a matriz explicativa 'governo estadual' e 'SABESP' (FOLHA DE SÃO PAULO, 2014).

Encontradas as principais lacunas, principalmente relaticadas a causas não climáticas, quais seriam os elementos que, em abordagens geográficas, poderiam concorrer para instrumentalizar outra matriz explicativa do ocorrido? A geografia poderia, com suas ênfases na análise do território e da produção do espaço, explorar outras facetas quanto às causas dessa crise?

Foram tratados outros elementos sem dar conta de todas as possibilidades de análise geográficas, em termos de perspectivas de análise, categorias, sistemas e escalas. Esses elementos, analisados individualmente e por vezes integrados no tempo e no espaço, mostraram-se úteis e relevantes não apenas para se apontarem prováveis responsabilidades da gestão governamental, como também para se aprender com os eventuais erros cometidos e para caracterizar decisões e políticas que se encaixam num ideário político específico. 


\section{Avaliação do papel da gestão governamental na atual crise de abasteci- mento da RMSP}

A gestão dos recursos hídricos no estado de São Paulo deve ser analisada em período mais longo do que o da admissão pública e divulgação ampla da existência de uma crise de abastecimento, devido às necessidades do próprio setor, que trabalha com planejamento de longo prazo. Dessa forma, elementos que revelam a política de gestão devem ser considerados.

Numa perspectiva variável de algumas décadas, são aqui tomados: os marcos regulatórios da gestão de recursos hídricos, elementos da gestão financeira, correlações entre crescimento populacional e capacidade dos sistemas produtores, comportamento do nível dos reservatórios do Sistema Cantareira, o avanço da degradação física do sistema produtor da Cantareira e os instrumentos de preservação e conservação.

Num outro bloco, faz-se uma breve caracterização climática da região e bacias produtoras de água para revisitar essa matriz explicativa da crise de abastecimento e do colapso do Sistema Cantareira.

Para esses elementos selecionados, levaram-se em consideração: intervalos decadais de número variável, o território efetivamente comprometido com a geração de água no sistema Cantareira, o território e a população efetivamente comprometidos em seu consumo.

\section{Aspectos legais, institucionais e financeiros}

Quanto ao que se pode denominar ambiente legal e institucional, é preciso considerar que o setor de recursos hídricos sofre mudanças e aperfeiçoamentos significativos desde o ano de 1989 e a década de 1990, seja no plano nacional ou no estadual. Foram criadas figuras de planejamento e gestão como a Agência Reguladora Nacional (ANA) e os comitês de bacias hidrográficas, entre outras relevantes para a gestão de recursos hídricos, acompanhando uma tendência internacional (Neder, 2008; Ribeiro, 2008).

No âmbito estadual, a partir da promulgação da Constituição Estadual inaugura-se uma nova política voltada à gestão de recursos hídricos, cuja execução é viabilizada em atendimento aos princípios básicos estabelecidos na Lei n. 7.663 (São Paulo, 1991). Entre os principais mecanismos estão: o Plano Estadual de Recursos Hídricos, o Fehidro, o Sistema Integrado de Gerenciamento de Recursos Hídricos, o Conselho Estadual de Recursos Hídricos e os Comitês de Bacias Hidrográficas.

Um dos pilares inspiradores dessas mudanças são as ações de caráter integrado pretendidas na gestão territorial, destacando-se nas disposições preliminares da Lei n. 7.663, em seu artigo 3०, os seguintes princípios:

I - gerenciamento descentralizado participativo e integrado [...]; II - adoção da bacia hidrográfica como unidade físico-territorial de planejamento e gerenciamento; III - reconhecimento do recurso hídrico como um bem público [...] observados os aspectos de quantidade e qualidade [...]; $\mathrm{V}$ - combate e prevenção de causas e efeitos adversos [...] inundações, estiagens; VII - compatibilização do gerenciamento de recursos hídricos com o desenvolvimento regional e com a proteção do meio ambiente (São Paulo, 1991). 
No âmbito estadual, entre outras atribuições, cabe à Secretaria de Saneamento e Energia, de acordo com a Lei n. 11.364, de 28 de março de 2003, e do Decreto n. 51.536, de 1 de fevereiro de 2007:

II - O planejamento e a execução das políticas estaduais de recursos hídricos e de saneamento básico em todo o território do estado de São Paulo, compreendendo: [...] captação, adução, tratamento e distribuição de água [...] III - estudo, planejamento, construção e operação de obras de infraestrutura de recursos hídricos, bem como a operação, manutenção de estruturas hidráulicas, compreendendo drenagem, erosão urbana e controle de enchentes (São Paulo, 2003).

Pela Lei n. 11.364/2003, Art. 62, e Lei Complementar n. 1025/2007, a Secretaria de Saneamento e Energia fica autorizada a atuar em conjunto com os titulares das demais pastas, com a finalidade de integrar as políticas de energia e saneamento básico com outras correlatas, em especial à do meio ambiente, recursos hídricos, saúde pública, desenvolvimento urbano e defesa do consumidor.

Ao longo dessas décadas, em que se desenvolve o quadro institucional e legal para a gestão dos recursos hídricos, já havia uma série de organismos internacionais consolidados, com suas orientações à gestão integrada, à prevenção, à pesquisa e à educação. Trata-se de uma época em que a preocupação com as mudanças climáticas já se anunciava, como se pode comprovar pela promulgação, junto à Unesco, do Programa Hidrológico Internacional (IHP) ou pela instauração do IPCC (International Panel of Climate Change), em 1988. A partir dessa década, um reconhecimento de nações e governos a respeito dos problemas de mudanças climáticas e se dá início a uma mudança de pauta nas agendas de organismos científicos internacionais com a divulgação regular de relatórios de avaliação sobre mudanças climáticas globais.

É justamente no bojo desse ambiente legal, institucional, e desse foco na pauta científica global - a das mudanças climáticas - que a Sabesp passa por mudanças estruturais do ponto de vista de sua organização empresarial, que irá de exclusivamente pública, para, em 1973, dar início à abertura de ações para a iniciativa privada, tornando-se empresa de capital aberto em 1995.

Nesse ano, a Sabesp descentraliza sua gestão em unidades de negócio, fazendo oferta pública em 2002 com suas ações listadas na bolsa de valores de Nova York, que hoje detém 24,0\% dessas ações, contra 25,7\% de ações da BM-Bovespa e 50,3\% de ações do governo do estado. Essa composição acionária a classifica como empresa público-privada de capital aberto, modelo esse que pode ter sido a mola propulsora para uma mudança de rumos quanto à prioridade dos investimentos de caráter preventivo, na contramão de princípios legais e da agenda científica global, com suas preocupações com as mudanças climáticas e o aumento de eventos extremos.

É claro que essa nova categoria de empresa por si só não seria fator suficiente para um redirecionamento de gestão financeira quanto à lucratividade da empresa a qualquer custo, pois existem mecanismos que, em tese, regulariam tais direcionamentos. Quanto a essa questão, Fagnani (2015) e Zuffo (2015) analisam dois aspectos restritivos ou menos eficazes dos marcos regulatórios para inibição do foco em lucratividade. Um deles seria a obrigatoriedade legal da Sabesp quanto ao reinvestimento dos recursos obtidos pela cobrança do uso da água 
bruta convertidos em infraestrutura. Outro é o da necessidade de submissão das decisões de gestão empresarial à agência reguladora. Segundo esses próprios estudiosos, nenhum desses dois fatores foi eficaz em seus propósitos fundamentais, que seria o do uso da água como recurso natural de "bem comum" a ser garantido a todos pelo Estado, ao qual a lucratividade deveria ficar subjugada.

Quanto à obrigatoriedade de reinvestimento em infraestrutura, principalmente a partir da possibilidade de cobrança pelo uso da água bruta, é notório, por exemplo, o fato de que se inicia uma tendência clara em relação à composição do montante dos investimentos por setor, estes sendo voltados mais para um dos itens de infraestrutura que é o da abertura necessária de novos atendimentos em serviços de ligações e coleta de esgoto. Mesmo tratando-se de serviço fundamental, é preciso lembrar que essa é ponta de todo o sistema de disponibilidade de água, que envolve desde infraestrutura de captação, armazenamento e tratamento, como de distribuição.

Então, seria de esperar que todas essas áreas recebessem atenção minimamente equivalente também a partir do período de mudança empresarial. Nesse sentido, os dados demonstram que havia saúde financeira para um equilibrio maior de investimentos entre os itens de infraestrutura.

A evolução do lucro líquido da Sabesp foi de R \$ 833 milhões em 2003 a R \$ 1,9 bilhão em 2013. Da mesma forma, houve uma evolução importante dos investimentos totais da empresa nesse mesmo período (Tabela 2). Em relatório de 2014 da própria Sabesp, observa-se que a maior parte dos investimentos desse ano ( $\mathrm{R} \$ 11,9$ bilhões nos últimos cinco anos) também foi para a rede de distribuição de água e coleta e tratamento de esgoto. Há elementos, portanto, para se apontar necessidade de aprofundamento nessa questão, pois, ao que indicam esses dados, houve defasagem quanto aos investimentos noutros itens de infraestrutura, em que se incluem novas captações, novos reservatórios, diminuição de perdas na distribuição e novas interligações.

\section{Tabela 2 - Investimentos da Sabesp em infraestrutura}

\begin{tabular}{cc}
\hline ano & investimento \\
\hline 2014 & $\mathrm{R} \$ 3,210$ bilhões \\
\hline 2013 & $\mathrm{R} \$ 2,716$ bilhões \\
\hline 2012 & $\mathrm{R} \$ 2,536$ bilhões \\
\hline 2011 & $\mathrm{R} \$ 2,440$ bilhões \\
\hline 2010 & $\mathrm{R} \$ 2,194$ bilhões \\
\hline 2009 & $\mathrm{R} \$ 2,059$ bilhões \\
\hline 2008 & $\mathrm{R} \$ 1,734$ bilhões \\
\hline 2007 & $\mathrm{R} \$ 921$ milhões \\
\hline 2006 & $\mathrm{R} \$ 905$ milhões \\
\hline 2005 & $\mathrm{R} \$ 678$ milhões \\
\hline 2004 & $\mathrm{R} \$ 601$ milhões \\
\hline 2003 & $\mathrm{R} \$ 594$ milhões \\
\hline total & $\mathrm{R} \$ 20,588$ bilhões \\
\hline
\end{tabular}

fonte: Relatório da Diretoria Econômico-Financeira e de Relações com Investidores da Sabesp (mar. 2015). 
Quanto à submissão por agência reguladora para aprovação dos investimentos, há também estudos em que se afirma que esta, quando passou a existir, não se caracterizou por uma atuação independente das políticas dos governos estaduais que se sucederam (Zuffo, 2015).

Zuffo (2015) chama atenção para outro aspecto da obrigatoriedade do reinvestimento em infraestrutura a partir da possibilidade de cobrança pelo uso da água bruta, no que se refere à forma como isso vem sendo feito.

Em primeiro lugar, aponta que há um congelamento de preços de reinvestimento em infraestrutura desde 2004 quanto à cobrança pelo uso da água bruta. Em segundo lugar, a empresa concessionária, no caso em questão, não encontra concorrência, o que configuraria uma situação de monopólio, que a distingue das concessões em geral, mesmo se tratando de um item essencial à vida. E, mesmo diante disso, essa concessionária, de caráter monopolista, será a dona da infraestrutura construída com os recursos financeiros captados, e não mais a bacia hidrográfica que gerou o recurso. Ainda segundo Zuffo (2015), com a empresa apresentando características de monopólio, haveria um contraditório, pois os investimentos em infraestrutura reduziriam as parcelas de dividendos que devem ser distribuídas aos acionistas.

Segundo Zuffo (2015), esses seriam marcos regulatórios que merecem ser revistos. Fagnani (2015) afirma que nesse desenho gerencial se inverteria a lógica do investimento em infraestrutura, com o lucro da empresa financiando o Estado, e não o contrário.

Essas análises dos marcos regulatórios, principalmente quanto à gestão financeira, demonstram a possibilidade da empresa ter atuado no sentido de uma inversão de prioridades. Fato esse que seria ainda mais agravado por se tratar de um item essencial à vida, um direito humano fundamental, já reconhecido como tal no pacto Internacional dos Direitos Econômicos, Sociais e Culturais, explicitados na Assembleia Geral da ONU de 28 de jultho de 2010.

Observando-se, então, a distribuição dos investimentos do período em análise, percebe-se que a maioria foi, de fato, voltada às novas ligações ou atendimentos sem equivalente e suficiente investimento infraestrutural em itens como diminuição de perdas, novas captações, novos reservatórios, alteamentos e interligações.

\section{A disponibilidade de água}

Conforme dito anteriormente, para se analisar a disponibilidade de água é necessário observar, tanto as variáveis naturais das áreas das bacias hidrográficas geradoras de água bruta mais independentes, como a climática, considerando a "entrada" de água e o estado de preservação das superfícies receptoras, quanto as variáveis dependentes de gestão, a exemplo da capacidade da infraestrutura para o uso dessa água de entrada. Associada a uma avaliação dos padrões de consumo, são esses os principais pontos que melhor instruem a avaliação de disponibilidade e de escassez, e, por meio deles, as responsabilidades dos atores sociais envolvidos.

Quanto à disponibilidade de água ligada à infraestrutura de captação, armazenamento, tratamento e distribuição da água tratada, fizeram-se dois tipos de análise. Um deles se deu por meio de dois parâmetros compondo um índice: o crescimento populacional da RMSP e o crescimento das estruturas hidráulicas de todo o sistema de abastecimento, parâmetros sintetizados em termos de disponibilidade total/população, ao longo dos últimos 80 anos em m³/s.

O outro foi o de observação do uso da capacidade máxima de produção de água do Sistema Cantareira, observando-se flutuações e extremos nos níveis de seus reservatórios nos últimos anos. 
Analisou-se não só a área envolvida com a geração de água do Sistema Cantareira, sistema responsável por aproximadamente 50\% do abastecimento de água da GSP, como também a principal área consumidora, que não é apenas a da bacia do Alto Tietê, mas a região metropolitana de São Paulo. Esses recortes espaciais devem ser utilizados nessas leituras, sem os quais pode haver distorção quanto ao significado dos dados, análises, projeções e planejamento. A necessidade de recortes espaciais mais fiéis aos territórios geradores, produtores e consumidores de água foi reconhecida no Plano de Gestão de Recursos Hídricos da Macrometrópole, publicado em 2015.

\section{Crescimento do consumo e sistemas produtores}

Mesmo considerando que o aumento populacional pode não levar ao aumento de padrão de consumo, o que ocorre ao longo dos últimos 30 anos na RMSP é, simultaneamente: aumento no padrão de consumo e aumento populacional, em taxas superiores à capacidade de geração de água de todos os sistemas envolvidos, que, ao contrário, sofrem retração relativa no período (Tabela 3). Segundo Côrtes e Torrente (2015), esse quadro estaria mais relacionado ao crescimento econômico e à consequente ascensão social do período, além do crescimento de setores econômicos de alto consumo, como o da construção civil, do que à melhoria dos hidrômetros e a aberturas de atendimentos.

\section{Tabela 3 - Crescimento populacional da RGSP e capacidade máxima de geração de água para abastecimento}

\begin{tabular}{cccc}
\hline ano & $\begin{array}{c}\text { população } \\
\text { (mi. habitantes) }\end{array}$ & $\begin{array}{c}\text { capacidade máxima } \\
\text { de produção }\left(\mathrm{m}^{3} / \mathrm{s}\right)\end{array}$ & $\begin{array}{c}\text { produção per capita } \\
\left(\mathrm{m}^{3} / \mathrm{s} / \mathrm{mi} \text {. hab. }\right)\end{array}$ \\
\hline 1958 & 3,5 & 8,3 & 2,37 \\
\hline 1980 & 12,5 & 59,7 & 4,77 \\
\hline 2000 & 17,9 & 64,0 & 3,57 \\
\hline $2014 / 15$ & 20,9 & 69,7 & 3,33 \\
\hline
\end{tabular}

fonte: Barros (2013), Emplasa (2015), História [...] (2015). organização: Cleide Rodrigues.

Observa-se que a retração relativa da disponibilidade do sistema hidráulico instalado para abastecer a RMSP ocorre principalmente a partir da década de 1980, com índices progressivamente menores, na contramão do quadro legal, institucional e das recomendações de caráter preventivo do meio técnico e dos organismos internacionais do setor. É importante lembrar que é nessa década que o Sistema Cantareira é concluído e começa a operar em sua plena capacidade, e que, a partir de então, durante mais de 30 anos, a relação entre população e volume de água produzido para a RMSP sofreu queda progressiva, apesar da entrada de vazões de outros sistemas de menor porte. Essa correlação é também indicativa de que se trabalhou na direção de um progressivo crescente risco na gestão dos recursos hídricos para a RMSP a partir da construção e operação do Sistema Cantareira. 
Os estudos de Côrtes e Torrente (2015), parcialmente retratados em matéria da Folha de S.Paulo em abril de 2014, demonstram que houve de fato uma mudança significativa no padrão de consumo. Segundo os dados analisados, entre 2004 e 2013, o consumo de água na RMSP teria subido 26\%, enquanto o volume teria aumentado apenas $9 \%$, o que explicaria a crise que, segundo o jornal, estaria se delineando. Essa mudança no padrão de consumo teria subido de 2004 a 2013 de 150 l/hab./dia para 175 l/hab./dia. A matéria levou em consideração a opinião de outro pesquisador, que atribui o aumento do consumo ao aumento da acurácia dos registros, em função da substituição dos hidrômetros antigos e quebrados, elemento não desprezível na análise (CONSUMO [...], 2014).

Esse tipo de análise, ainda que careça de maior aprofundamento, é indicativa da supremacia dos objetivos de ordem econômica e política na tomada de decisões na gestão dos recursos hídricos do estado de São Paulo no período analisado, com decisão sobrepondo-se a recomendações técnicas em diversos níveis. Trata-se de mais um conjunto de evidências que convergem para a matriz explicativa "gestão".

\section{Sinais de esgotamento do Sistema Cantareira}

Outra evidência do crescente risco assumido na gestão de recursos hídricos é o fato de todo o Sistema Cantareira ter sido utilizado em sua capacidade máxima durante, ao menos, os últimos 15 anos. Ao longo desse período, foram realizadas mais de 100 visitas de campo anuais ao Sistema Cantareira, em quatro pontos estratégicos da entrada e saída de água do sistema, levantando-se in loco dados oficiais e realizando em gabinete algumas conferências dos dados oficiais, além de terem sido gerados dados primários de alguns desses pontos, como a entrada de água das bacias do rio Jaguari.

Os pontos visitados foram: A ETA Guaraú, a ESI Santa Inês, o reservatório Paiva Castro, os reservatórios Jaguari-Jacareí, a afluência do rio Jaguari para entrada de água no sistema (com levantamento de vazão) e a saída de água na Estação Guaripocaba. Apesar de essas atividades apresentarem inicialmente objetivos pedagógicos, acabaram por viabilizar pesquisas complementares, principalmente quanto à constatação do uso maximizado do potencial gerador do sistema. Esses estudos também focalizaram os sinais físicos de mudança no balanço hídrico das bacias, conforme adiante.

A partir dos levantamentos sistemáticos de vazão na entrada de água das bacias do rio Jaguari, foi evidenciada a relevância do território mineiro na geração de água bruta e na produção de água tratada do Sistema Cantareira e do Sistema de abastecimento da RMSP como um todo. Essa, de fato, ainda é a maior área de mananciais de São Paulo, com uma contribuição média que corresponde a quase 50\% de todo o abastecimento da RMSP. Observou-se ao longo do período de 15 anos que, fosse próximo do verão ou inverno, o sistema estava trabalhando com tratamento ininterrupto de $33 \mathrm{~m}^{3} / \mathrm{s}$ que é a capacidade máxima operacional do sistema de tratamento e distribuição. Os estudos do ISA (2007) também contribuíram para se compreender o verdadeiro território comprometido na produção de água do Sistema Cantareira, principalmente com produção de mapas diversos e, entre eles, os de uso da terra das bacias hidrográficas (Figura 1). 


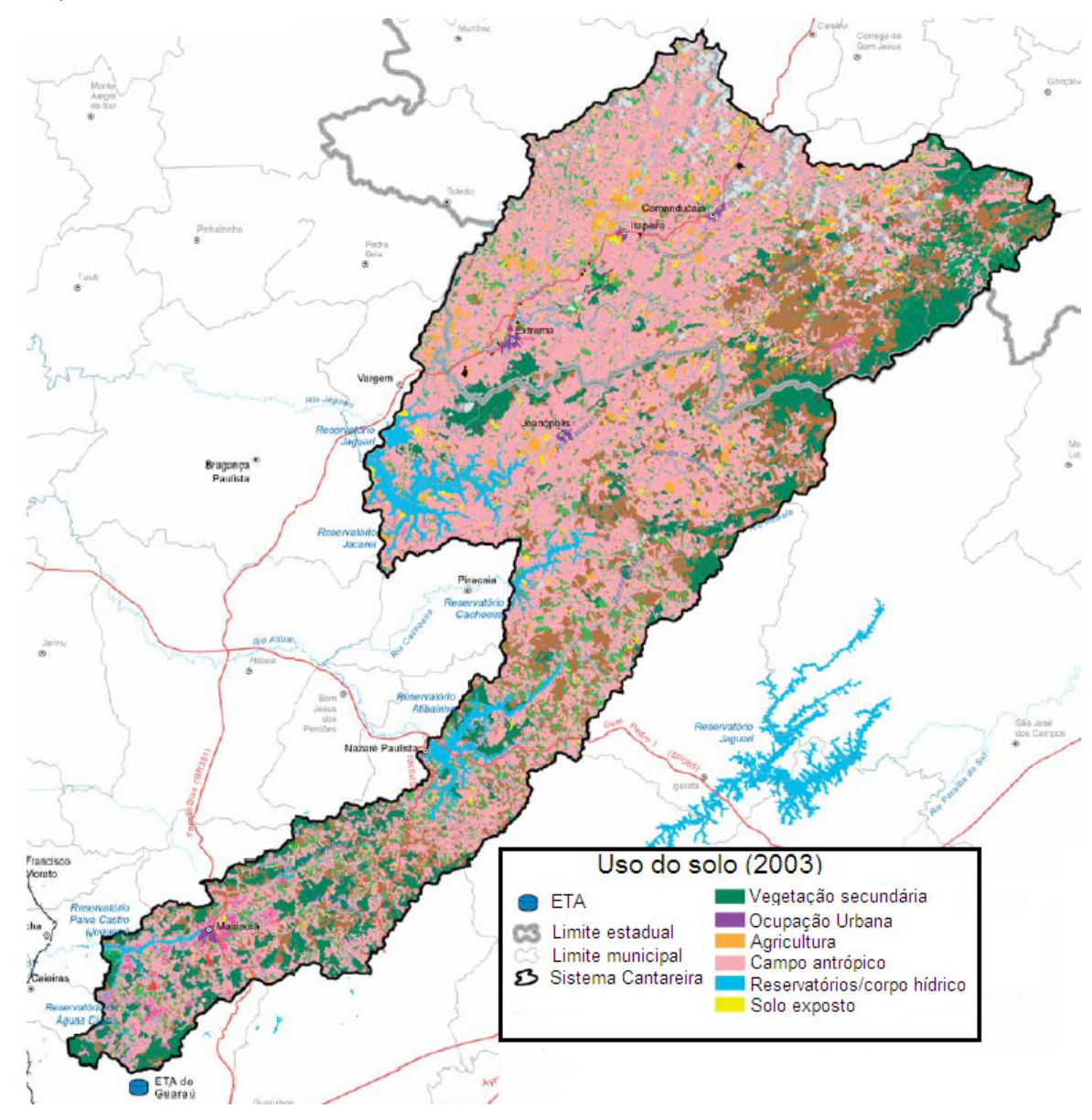

fonte: ISA (2007).

Verificou-se, por exemplo, que em 2003, 70\% da área dos mananciais do Sistema produtor da Cantareira já observava uso antrópico, sendo a maior parte de pastagem (51\%). Esse é um tipo de uso cuja combinação com tipos de solo e relevo configura risco potencial para a manutenção do balanço hidrológico original e preservação de um maior tempo de residência da água no sistema.

O objetivo dos estudos realizados posteriormente foi levantar evidências de degradação física dos sistemas fluviais e de vertentes da área das bacias hidrográficas do rio Jaguari, agora consideradas como as principais áreas de mananciais da região metropolitana de São Paulo. Um dos exemplos é o estudo de Giroldo (2013), que evidencia a significativa mudança de um dos parâmetros físicos do solo relacionado a sua degradação física, de resistência à penetração, por sua vez associado ao aumento de densidade total e compactação do solo, provocados pelo pisoteio do gado.

A autora demonstra que, na maior parte dos ensaios e medidas, os níveis de resistência ultrapassam o limiar de enraizamento das próprias espécies de gramíneas utilizadas na atividade pastoril, diferentemente das medidas obtidas em áreas florestadas. Certamente, esse é um indicador indireto de que houve significativa mudança no ciclo hidrológico dessas bacias a partir dessa modalidade de uso do solo, com incremento ainda não reconhecido de vazões extremas 
e consequente diminuição de estoques de subsuperfície. Como raciocínio consequente desse fato, deve ser lembrada a diminuição do tempo de concentração da água nas bacias hidrográficas produtoras, que vai implicar desperdício de água, pois os sistemas de armazenamento não comportam "segurar" as vazões extremas que chegam rapidamente aos reservatórios, com risco de rompimento das estruturas hidráulicas.

Os estudos de Maestu (2008) também evidenciam, por meio de geoindicadores de sistemas fluviais, um provável e recente (última década) aumento na magnitude e frequência de vazões extremas em sub-bacia do rio Jaguari, em que se observou a destruição de um sistema fluvial meândrico em rio de terceira ordem. Na literatura sobre geomorfologia fluvial, esses sistemas são formados num intervalo temporal variável de centenas a milhares de anos, entre outros fatores, em função da ordem fluvial correspondente. Contudo, ao longo de apenas uma década, verificou-se sua progressiva destruição, muito provavelmente ligada ao aumento antrópico da magnitude e frequência de vazões extremas nas bacias produtoras.

Só a partir dos últimos anos alguns estudos começam a ser desenvolvidos sobre o monitoramento hidrológico dessas áreas produtoras, inclusive com a criação de uma nova estação fluviométrica no ponto em que, há mais de 15 anos, selecionamos para as visitas sistemáticas, só implementado em 2014, após a instauração da crise (3D-016 - Pires). Com essas informações, pretende-se ponderar que foi de fato tardia a preocupação dos órgãos gestores e das figuras institucionais na proteção da mais importante área de mananciais para a RMSP e que, ainda hoje, mesmo a cobrança do uso de água bruta sendo revertida para as bacias produtoras, os estudos são incipientes e os instrumentos de proteção, dos mais fracos entre as categorias do Snuc (Sistema Nacional de Unidades de Conservação). Além da legislação ambiental de níveis federal e estadual mais geral, incidem sobre a área em questão instrumentos como Áreas de Proteção Ambiental (APA) tais como a APA do rio Piracicaba e de Juqueri Mirim (Área II, Decreto de 1987), a APA do Sistema Cantareira (Lei Estadual de 1998) e a APA Fernão Dias (decretada em 1987). Esta última, a cargo do governo de Minas Gerais, é a que está mais desenvolvida em relação a seu plano de gestão. As demais ainda não concluíram seus planos de manejo, estando, portanto, sem regulamentação.

Conclui-se que, mesmo sendo os municípios os soberanos na legislação sobre o uso da terra, houve pouco empenho ao longo de todos esses anos dos diversos níveis de governo, principalmente do governo estadual paulista e da Sabesp, no sentido de se estudarem e monitorarem as variáveis hidrológicas desses mananciais e de se criar mecanismos efetivos para sua proteção. Estudos efetivos iniciaram-se tardiamente, e as ações neles parametrizadas, são, portanto, frágeis, principalmente no sentido de aumentar as possibilidades de se armazenar a água da chuva nos níveis do solo ou subsolo e contribuir para o maior tempo de residência da água nos sistemas de vertente e fluviais dessas bacias produtoras de água bruta.

Do ponto de vista do comportamento dos níveis dos reservatórios do sistema Cantareira, o exercício realizado foi o de observar, ao longo dos últimos 15 anos, quais foram os principais picos de reserva, com reservas máximas e mínimas. Esse dado merece ser mais bem explorado nas análises sobre o ocorrido, tendo em vista que alguns alertas poderiam ter sido utilizados para mudança de rumo nas diversas ações e investimentos infraestruturais do planejamento preventivo. 
Whately (2004) alertava para o fato de que, em 2003, os níveis médios dos reservatórios do Sistema Cantareira teriam chegado a limites críticos, sem que se considerasse, do ponto de vista climático, que estaríamos diante de um fenômeno de seca ou estiagem severa (Gráfico 1). Mesmo tendo mudado a referência para aquilo que hoje se considera volume morto - mudada três vezes ao longo destes 15 anos (Zuffo, 2015) -, é possível verificar no Gráfico 1 que existe uma flutuação importante nos níveis dos reservatórios do sistema em questão, demonstrando grande dependência da entrada de chuva.

Gráfico 1 - Oscilação dos reservatórios do Sistema Cantareira (jan. 2013/ fev. 2014)

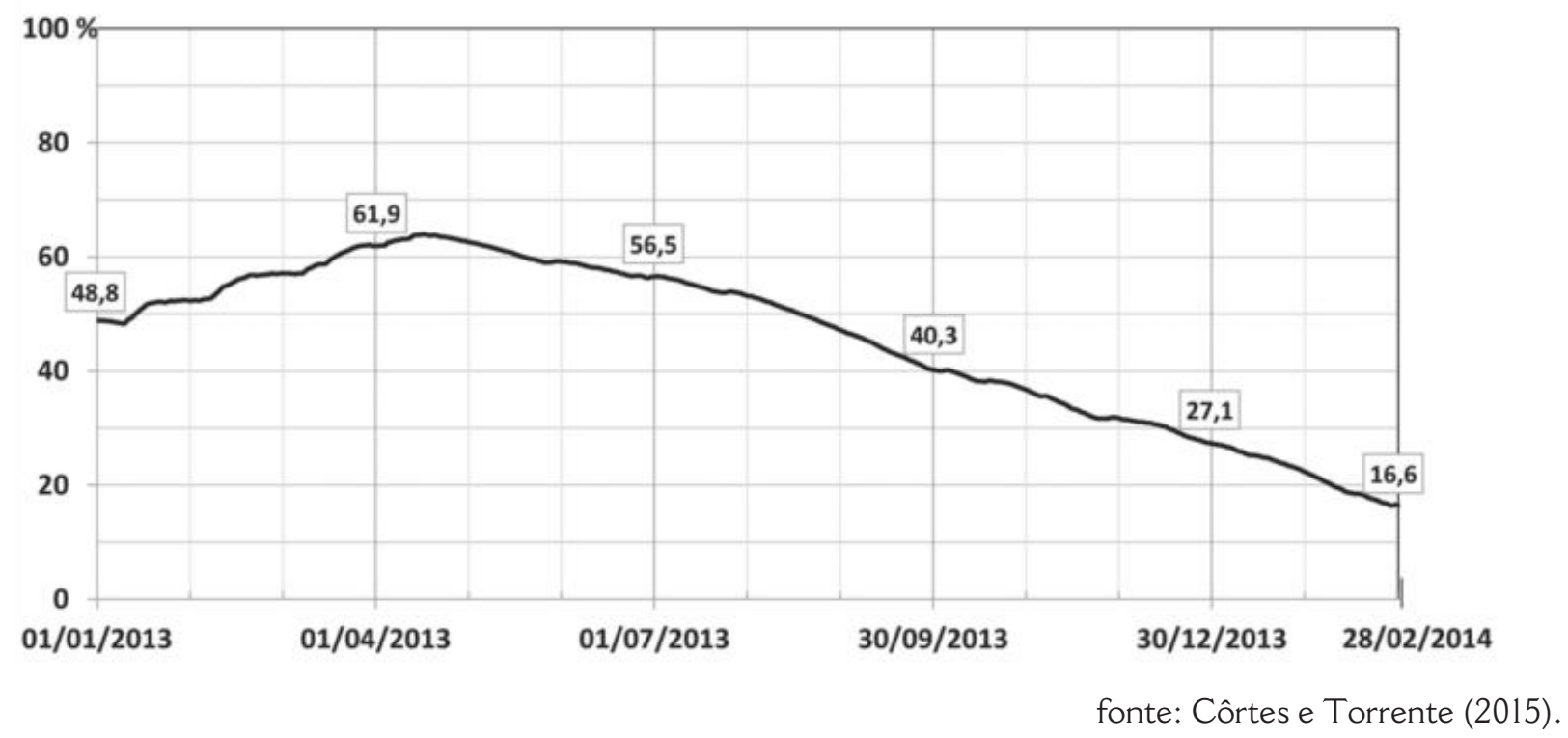

Ao longo do período representado no Gráfico 2, observam-se picos atingindo tanto os limites críticos, próximos ao volume morto (cambiante em torno de 10\%), um em 2003 e outro em 2014.

\section{Gráfico 2 - Evolução do nível de armazenamento do Sistema Cantareira} (dez. 2003/dez.2011)

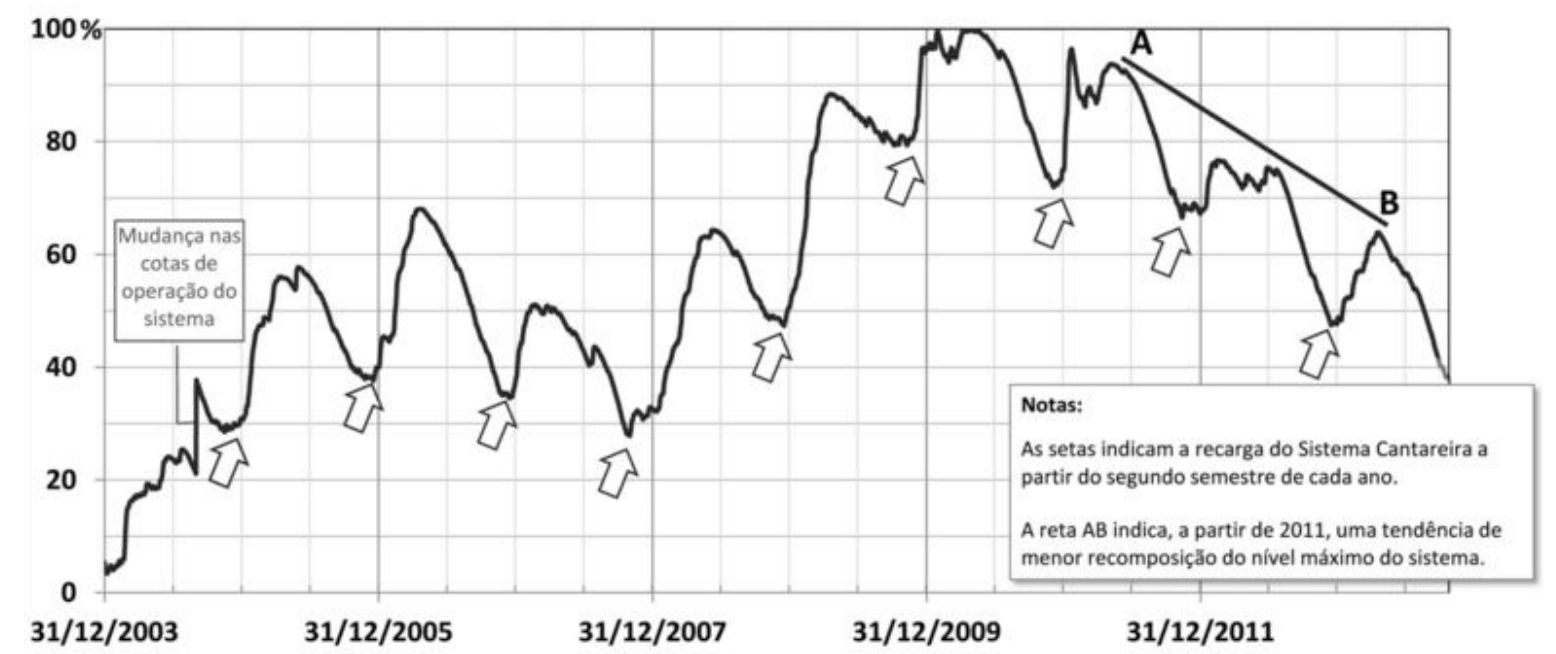

fonte: Côrtes e Torrente (2015). 
No verão de 2011, a vazão de pico das bacias hidrográficas produtoras de água bruta atingiu a máxima capacidade de reserva, e vazões significativas foram vertidas e perdidas a jusante de todo o sistema, que esgotou sua capacidade de armazenamento no episódio, colocando em risco suas estruturas e populações a jusante do sistema. Menos de quatro anos depois, já nos encontrávamos novamente no limite do volume morto, como em 2003.

\section{A questão climática: outros elementos}

A região onde fica o reservatório Jaguari-Jacareí sofre influência climática de sistemas globais/mesoregionais e da topografia circundante, seja por atuarem na heterogeneidade da distribuição da precipitação e do escoamento superficial, seja por direcionarem parte dos ventos resultantes dos deslocamentos das massas de ar, destacando-se, portanto, os fatores de maritimidade/continentalidade e orografia. Enquanto a maritimidade atua como regulador térmico e de umidade, a disposição do relevo atua na distribuição espacial da pluviosidade (Nunes; Vicente; Candido, 2009), havendo ainda influência da continentalidade na circulação das massas.

Os sistemas atmosféricos globais/mesoregionais afetam a região Sudeste do país e por consequência o estado de São Paulo, caracterizando parte do clima existente na região da Cantareira. Três massas de ar atuam de maneira significativa: a massa de ar polar, a massa de ar tropical temperada ou úmida e a massa de ar tropical seca e quente (Schroder, 1956), e, nesse ínterim, são frequentes as ações de sistemas frontais, onde em média ocorrem três frentes frias por mês num intervalo de 10 dias na Grande São Paulo, com frequência maior na primavera e menor no verão (Morais; Castro; Tundisi, 2010). Estas frentes encontram barreira natural na Serra da Cantareira para seu deslocamento rumo ao norte, concentrando-se muitas vezes na RMSP.

A proximidade da Grande São Paulo e da região da Serra da Cantareira para com a latitude do Trópico de Capricórnio implica em climas tropicais úmidos de altitude, com período mais seco definido, e climas subtropicais, permanentemente úmidos; uma das principais características climáticas dessa transição seria a alternância de estações quentes e úmidas e outras estações frias relativamente mais secas, com variações bruscas sujeitas a intenso aquecimento ou resfriamento em períodos de curta duração (dias a semanas) (Tarifa; Armani, 2001). A região onde ficam os reservatórios Jaguari- Jacareí sofre ainda efeito de sotavento da barreira da Serra da Cantareira e da altitude, modificando a distribuição da precipitação e condições das variações térmicas. Aliado a esses fatores há ainda o efeito da ação antrópica, pois a retirada da cobertura vegetal reduz a capacidade de retenção de energia solar pela superfície degradada elevando o albedo, contribuindo na inibição da convecção e condensação e desestimulando a formação de nuvens de chuva (Conti, 2003).

É nítida a influência da topografia em relação aos sistemas frontais oriundos do Oceano Atlântico quanto ao complexo serrano da Cantareira. Para atingir o núcleo da região metropolitana de São Paulo, por exemplo, é preciso que as massas de ar transponham a Serra do Mar, vencendo uma altitude de mais de $700 \mathrm{~m}$; para que haja alcance dos reservatórios Jaguari-Jacareí, na bacia hidrográfica do rio Jaguari, são necessários ao menos mais $400 \mathrm{~m}$ (SRTM, 2000). A absorção de umidade por parte do continente, com seus variados usos da terra decorrentes da ação antrópica, acaba por inibir os movimentos convectivos, a formação de nuvens e a consequente precipitação no setor montante das bacias, além do efeito orográfico já mencionado. No entanto, é necessário lembrar que ocorrem na região massas de ar advectadas de nordeste e leste, cuja interação da atmosfera com a superfície aquecida provoca intensa convecção, condensação e precipitação, sem necessariamente serem barradas pelo relevo, já que atuam paralelas às serras (Prado, 2010). 
Além disso, também podem ser mencionados os fenômenos de interação oceano-atmosfera como o El Niño e La Niña, que impactam os padrões de circulações atmosféricas globais (Trenberth, 1997), além de variações como a Oscilação Decadal do Pacífico (Prado, 2010; Garreaud; Battisti, 1999). Tais variações, consideradas não lineares, podem ser observadas como anomalias, representando importantes objetos de análise para previsões meteorológicas (Teixeira; Satyamurty, 2007), influindo para alguns na recarga de reservatórios e disponibilidade hídrica superficial (Côrtes; Torrente, 2015; Silva Dias et al., 2013; Santos et al., 2012).

Desse modo, verifica-se que a GSP e a região da Cantareira estão sujeitas a diversas influências climáticas de magnitudes e frequências variadas, com mecanismos ainda pouco conhecidos quanto aos impactos regionais e locais quando comparados aos mesoregionais.

Interpreta-se como agravante o fato de que o menor volume de chuvas nos últimos anos na Serra da Cantareira vem sendo acompanhado de extremo calor e de baixos índices de umidade, intensificando a evaporação, precipitando de maneira muito localizada e ocasionando a contínua redução dos níveis dos reservatórios que abastecem os principais municípios do estado, especialmente nas áreas mais populosas (Inmet, 2014). O posto meteorológico do Mirante de Santana, do Instituto Nacional de Meteorologia, bateu recorde de temperatura em 2014, alcançando $34,5{ }^{\circ} \mathrm{C}$ no fim de janeiro, mês com precipitação de $237,9 \mathrm{~mm}$, valor abaixo da média do período medido de 1943 a 2015 - 262,4 mm para janeiro, segundo o Inmet (2016). Dias quentes aumentam a evaporação da água armazenada no solo e corpos d' água, podendo haver déficit hídrico se a mesma exceder a precipitação. No entanto, no Sistema Cantareira não há déficit periódico nas precipitações que possam ser associados à escassez no volume dos reservatórios, e no tocante aos ritmos temporais que caracterizam o clima tropical de altitude não há individualização de estiagens bem definidas, como será demonstrado a seguir.

As séries temporais são indicadores quantitativos e é possível descrever-se o comportamento das entradas de água caracterizadas pelas precipitações por meio da análise de tendências, ciclos, variabilidades ou até mesmo aleatoriedades ou irregularidades (Conti, 2003). Os montantes chuvosos das estações da primavera e verão teriam de contrastar com déficits hídricos periódicos ao longo de uma série climatológica histórica, para haver caracterizadamente período seco ou estiagem expressos em valores médios. Não há, porém, consenso sobre critérios para se definir mês seco (Conti, 2008), sendo usual estabelecer-se o balanço hídrico anual ao contabilizar-se a variação do volume de chuvas, temperatura e evapotranspiração potencial. Outro caminho seria definir "seca" segundo critérios da Organização Meteorológica Mundial (OMM), que aponta sua ocorrência em uma região quando a precipitação anual for inferior a 60\% da normal durante mais de dois anos consecutivos e em mais de 50\% de sua superfície (Colville, $1987^{1}$ apud Conti, 2008).

A estação pluviométrica do Departamento de Águas e Energia Elétrica do Estado de São Paulo (Daee), localizada no município de Vargem-SP, a apenas 5 km dos reservatórios Jaguari-Jacareí, região serrana da Cantareira (Figura 2), viabilizou a leitura de precipitação ao longo de uma série histórica. Mesmo sem haver dados de temperatura e evapotranspiração potencial, a pluviometria da referida estação permite melhor compreender as entradas de água por ter dados desde 1937 e encontrar-se na bacia hidrográfica do rio Jaguari, que comporta os referidos reservatórios. Sua série histórico-pluviométrica, embora com lacunas, demonstra serem as estiagens que atingem o Sistema Cantareira de caráter isolado. $\bigcirc$ Gráfico 3 apresenta as precipitações totais anuais entre 1937 e 2015, e o Gráfico 4, as precipitações médias e respectivos desvios-padrão no mesmo período.

1 COLVILLE, P. G. Condicionantes climáticas: desertificação. Talca: Facultad de Ciencias Agrarias, Universidad de Talca, Chile, 1987. 
Figura 2 - Localização do Posto D3-018 em Vargem-SP, na Serra da Cantareira

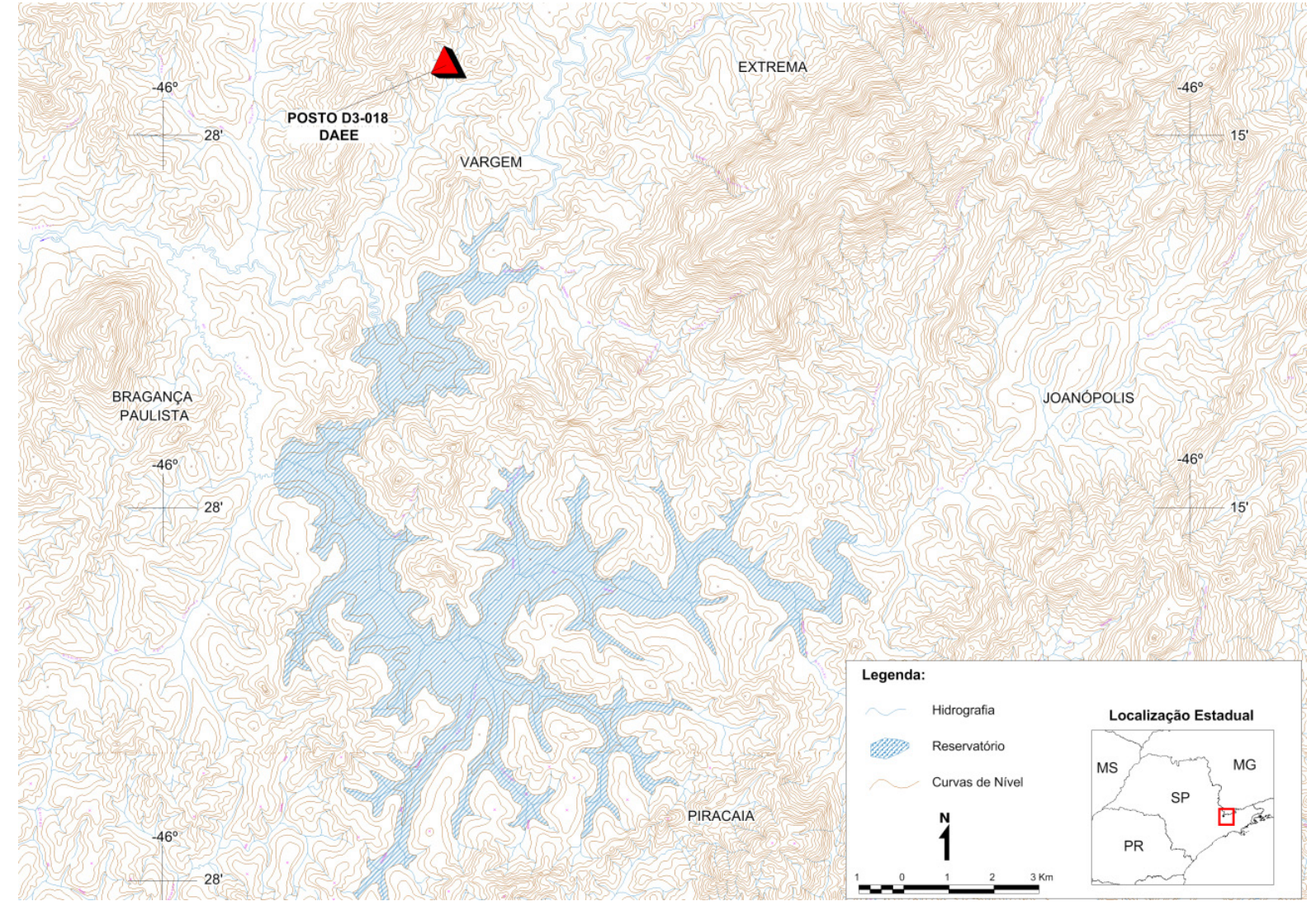

fonte: Daee (2016). organização: Fernando Nadal Junqueira Villela.

Gráfico 3 - Precipitação total anual (em $\mathrm{mm}$ ) para a Serra da Cantareira (Posto D3-018, Vargem-SP) (1937-2015

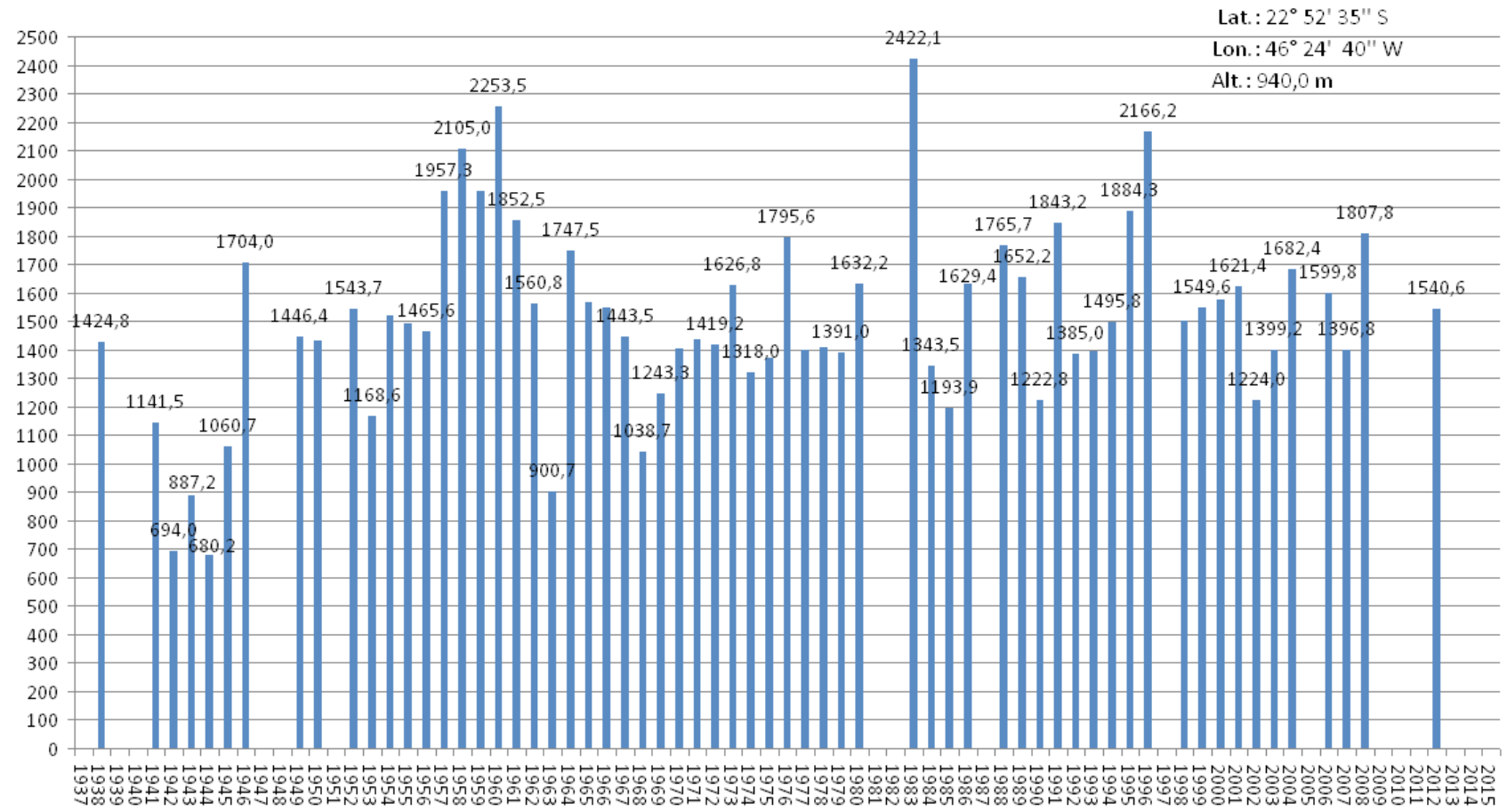

fonte: Daee (2016). organização: Fernando Nadal Junqueira Villela. 
Muitos anos não têm dados completos no Gráfico 3, o que impossibilita a verificação dos totais anuais de chuva, especialmente para 2005, 2009, 2010, 2011, 2013, 2014 e 2015. Contabilizando-se os anos em que não há falhas nas leituras, há uma média pluviométrica anual de 1.505,3 mm, onde o menor volume de chuvas ocorreu em 1944 (680,2 mm) e o maior volume em 1983 (2.422,1 mm). Se for considerado o critério da OMM anteriormente citado, os anos secos situar-se-iam abaixo da faixa de $900 \mathrm{~mm}$, sendo portanto relacionados a 1942, 1943 e 1944, três anos seguidos realmente "secos" que apontariam estiagem definida.

\section{Gráfico 4 - Precipitação média mensal e desvio padrão (em $\mathrm{mm}$ ) para a Serra da Cantareira (Posto D3-018, Vargem-SP) (1937-2015)}

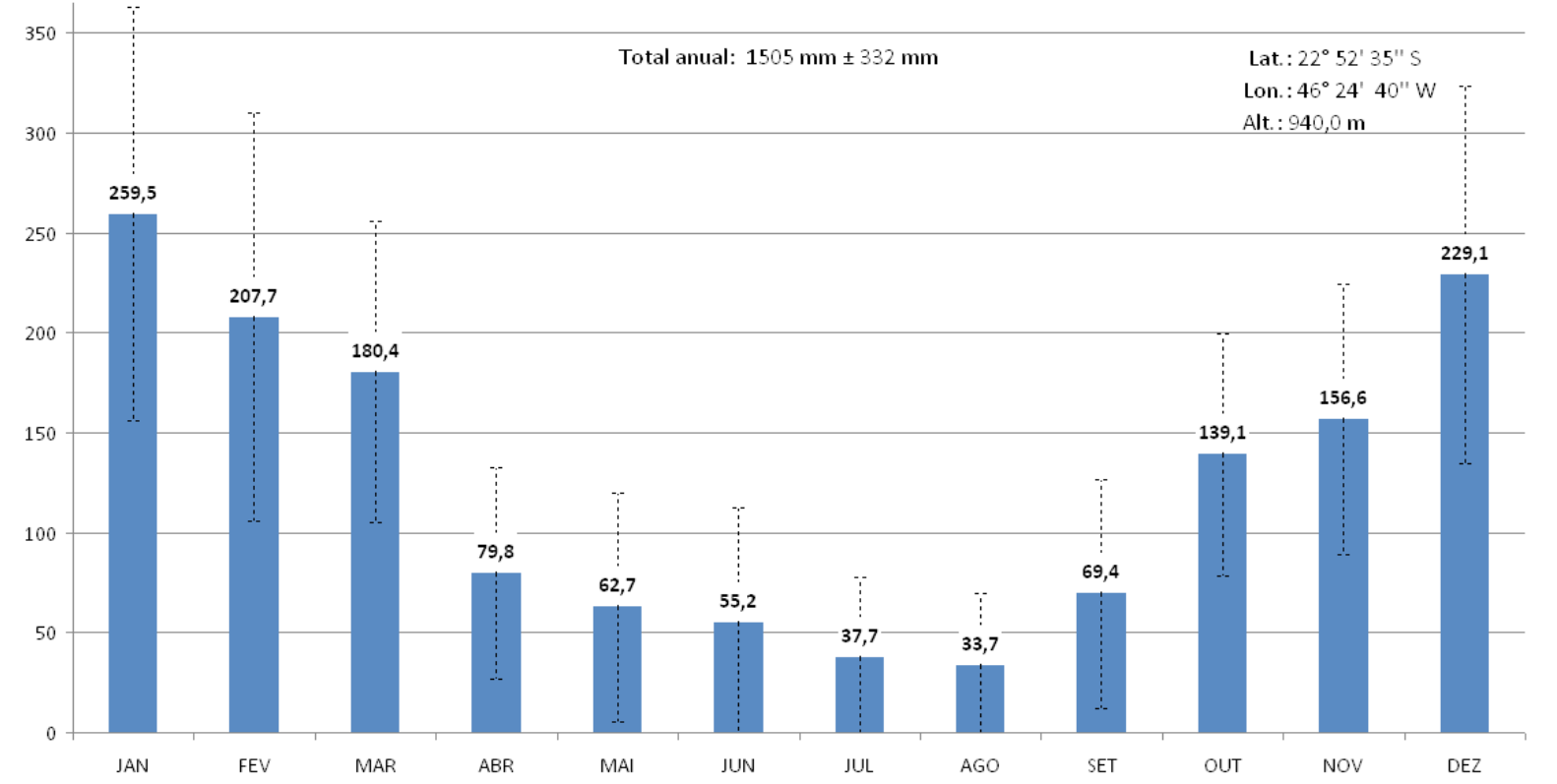

fonte: Daee (2016). organização: Fernando Nadal Junqueira Villela.

Já o Gráfico 4 mostra um período mais chuvoso nos meses de dezembro a março, com diminuição considerável mas não mínima das chuvas de abril a agosto, variabilidade associada ao clima tropical de altitude. De setembro a novembro há aumento progressivo da pluviometria, caracterizando um total anual médio de $1505 \mathrm{~mm}$ com variações de até $332 \mathrm{~mm}$, para mais ou para menos. É importante ressaltar que de todo o período medido, a maior chuva mensal foi no mês de janeiro de 1999, com 575 mm (Daee, 2016).

Observa-se pelos desvios-padrão que a variação da precipitação de acordo com os meses é acentuada, o que denota as variadas influências atmosféricas apontadas anteriormente. Os meses mais secos (abril a setembro) têm variação do desvio-padrão maior que seus valores médios, sendo que junho, julho e agosto apontam a possibilidade da falta de chuvas. Entretanto, o comportamento apresentado no Gráfico 4 para esses três meses apresenta chuvas abaixo de 60 mm, não verificando-se, na média, o que poderia ser caracterizado como estiagem.

As variações pluviométricas nesta estação da Serra da Cantareira decorrem da distribuição e frequência irregular das chuvas, comportamento que acabou por chamar mais atenção da mídia a partir da década de 2000 em razão das discussões sobre a falta d'água, mudanças 
climáticas, intensificação do efeito estufa e consequências do aquecimento global (Pereira Filho, 2015; Jacobi; Cibim; Leão, 2015). Para que se verifiquem as variações nesse período, a Tabela 4 e o Gráfico 5 apresentam as precipitações mensais do mesmo posto pluviométrico entre 2000 e 2015.

\section{Gráfico 5 - Precipitação média mensal (em $\mathrm{mm}$ ) para a Serra da Cantar- eira (Posto D3-018, Vargem-SP) (2000-2015)}

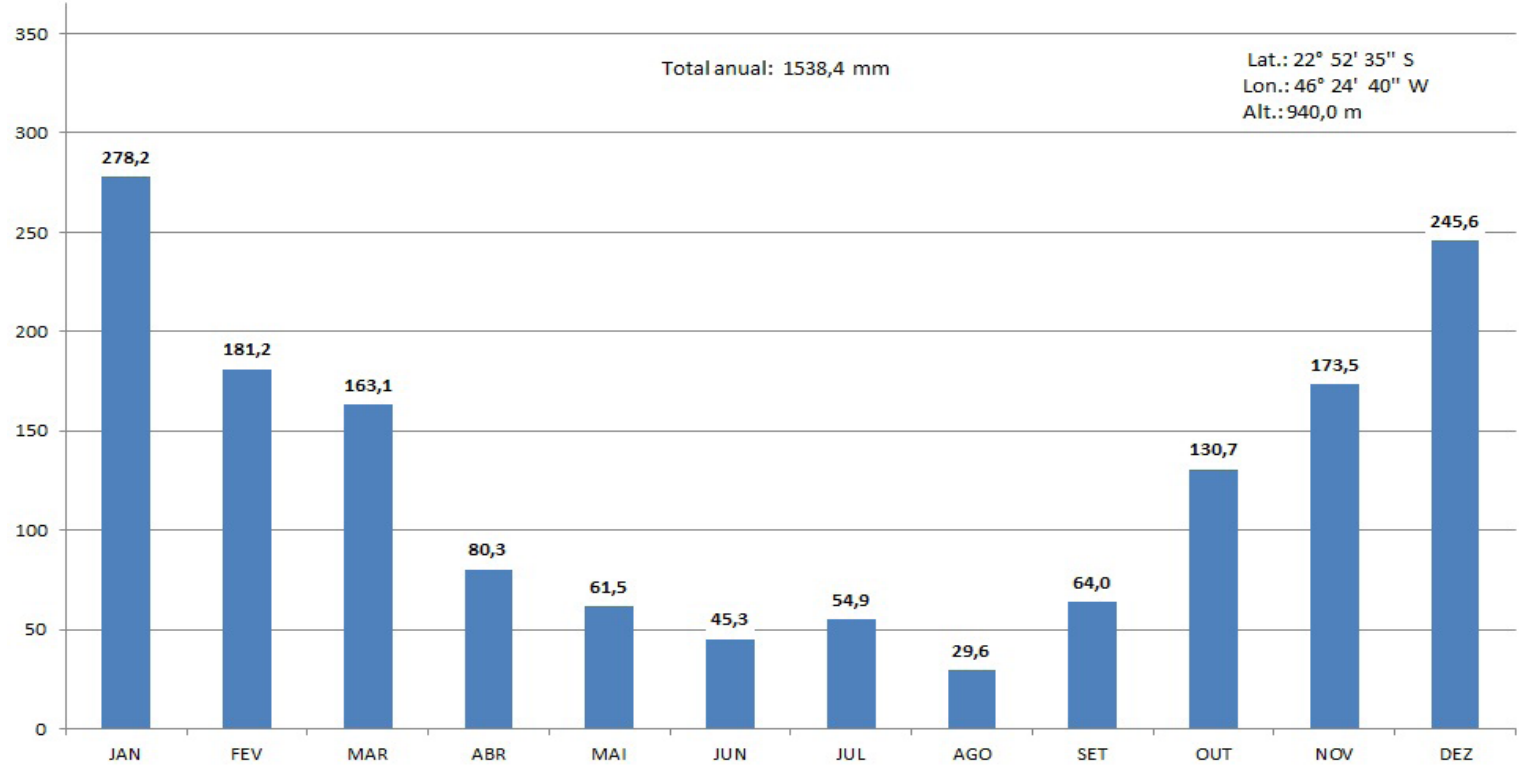

fonte: Daee (2016). organização: Fernando Nadal Junqueira Villela.

Tabela 4 - Valores mensais, totais anuais, valores mínimos e máximos no mês, médias mensais e média total de precipitações $(\mathrm{em} \mathrm{mm}$ ) para a Serra da Cantareira (Posto D3-018, Vargem-SP) (2000-2015)

\begin{tabular}{|c|c|c|c|c|c|c|c|c|c|c|c|c|c|c|c|}
\hline Ano & JAN & FEV & MAR & ABR & MAI & JUN & JUL & AGO & SET & OUT & NOV & DEZ & Total & Prec. Mín. & Prec. Máx. \\
\hline 2000 & 283,5 & 220,7 & 111,6 & 33,4 & 13,6 & 11,2 & 75,5 & 74,1 & 105,1 & 37,3 & 299,1 & 308,6 & 1573,7 & 11,2 & 308,6 \\
\hline 2001 & 208,8 & 185,9 & 132,6 & 79,6 & 67,3 & 11,7 & 20,6 & 51,6 & 84,6 & 204,3 & 221,1 & 353,3 & 1621,4 & 11,7 & 353,3 \\
\hline 2002 & 297,2 & 121,7 & 122,2 & 58,9 & 58,1 & 2,3 & 11,1 & 97,8 & 98,4 & 61,8 & 106,8 & 187,7 & 1224,0 & 2,3 & 297,2 \\
\hline 2003 & 344,5 & 142,2 & 112,6 & 50,9 & 55,9 & 7,1 & 14,0 & 20,1 & 28,0 & 185,0 & 168,1 & 270,8 & 1399,2 & 7,1 & 344,5 \\
\hline 2004 & 188,1 & 258,3 & 112,1 & 132,2 & 142,5 & 85,2 & 92,2 & 0,5 & 62,7 & 180,6 & 162,1 & 265,9 & 1682,4 & 0,5 & 265,9 \\
\hline 2005 & - & 78,0 & 211,2 & 43,2 & 215,2 & 22,2 & 18,0 & 16,5 & 94,4 & 148,9 & 123,5 & 221,5 & & 16,5 & 221,5 \\
\hline 2006 & 238,7 & 362,4 & 191,3 & 32,9 & 21,2 & 21,6 & 52,8 & 17,8 & 86,4 & 99,6 & 146,5 & 328,6 & 1599,8 & 17,8 & 362,4 \\
\hline 2007 & 292,2 & 72,4 & 125,4 & 73,5 & 51,7 & 61,8 & 185,4 & 0,0 & 15,2 & 96,4 & 289,6 & 133,2 & 1396,8 & 0,0 & 292,2 \\
\hline 2008 & 313,2 & 129,1 & 326,8 & 211,8 & 40,0 & 77,8 & 0,0 & 69,7 & 53,4 & 161,0 & 70,1 & 354,9 & 1807,8 & 0,0 & 354,9 \\
\hline 2009 & 425,1 & 263,2 & 157,2 & 13,0 & 41,5 & 72,7 & 105,9 & 54,0 & 80,2 & 110,2 & - & 410,9 & & 13,0 & 425,1 \\
\hline 2010 & 361,6 & -- & 192,3 & 75,4 & 10,2 & 23,2 & 58,1 & 0,3 & 81,1 & 89,7 & 221,5 & 198,7 & & 0,3 & 361,6 \\
\hline 2011 & 540,4 & -- & - & 94,4 & 21,6 & 34,4 & 1,5 & 19,6 & 18,8 & 152,6 & 246,7 & 94,6 & & 1,5 & 540,4 \\
\hline 2012 & 287,9 & 153,6 & 87,1 & 136,5 & 74,8 & 172,0 & 66,5 & 0,4 & 16,9 & 218,8 & 130,7 & 195,4 & 1540,6 & 0,4 & 287,9 \\
\hline 2013 & 203,7 & 246,4 & 158,4 & 86,8 & 54,4 & 66,4 & - & 8,9 & 36,2 & 159,7 & 123,2 & 114,7 & & 8,9 & 246,4 \\
\hline 2014 & 83,8 & 93,6 & 204,3 & 60,5 & 31,2 & 10,5 & 66,6 & 12,7 & 98,6 & 55,2 & 120,4 & - & & 10,5 & 204,3 \\
\hline 2015 & 103,6 & 208,6 & 201,5 & 101,7 & 85,1 & & & & & & & & & & \\
\hline Média & 278,2 & 181,2 & 163,1 & 80,3 & 61,5 & 45,3 & 54,9 & 29,6 & 64,0 & 130,7 & 173,5 & 245,6 & 1538,4 & & - \\
\hline
\end{tabular}

fonte: Daee (2016). organização: Fernando Nadal Junqueira Villela.

Contrariamente ao que se afirma, o período entre 2000 e 2015, considerado no Gráfico 5 e na Tabela 4, apresentou precipitação total acima da média do período entre 1937 e 2015 $(1.538,4 \mathrm{~mm} \times 1.505,3 \mathrm{~mm}$, respectivamente). Os volumes de chuva ocorridos mês a mês, 
quando registrados, mantiveram o padrão mais chuvoso nos meses de verão, diminuição das precipitações nas estações do outono e inverno e aumento progressivo das chuvas na primavera. Alguns meses não apresentaram registros, alterando os valores médios.

Entre 2000 e 2015, o posto pluviométrico de Vargem-SP registrou médias superiores à média histórica nos meses de dezembro $(245,6 \times 229,1 \mathrm{~mm})$ e janeiro $(278,2 \times 259,5 \mathrm{~mm})$, enquanto os meses de fevereiro e março foram inferiores (181,2 × 207,7 mm e 163,1 x 180,4 mm, respectivamente); assim, os dois meses mais chuvosos entre 2000 e 2015 não tiveram nem 20 mm (8\%) de chuva a mais que os dados acumulados de 79 anos da estação considerada. Por outro lado, os meses de fevereiro e março tiveram entre 2000 e 2015 quase 30 mm (13\%) e 20 $\mathrm{mm}(10 \%)$ a menos de precipitação que todo o período medido.

Do outono à primavera, as diferenças médias entre 2000-2015 e 1937-2015 foram mínimas, exceto em julho $(54,9 \times 37,7 \mathrm{~mm})$ e novembro $(173,5 \times 156,6 \mathrm{~mm})$. Ressalta-se que em razão da diferença do período de amostragem ( $15 \times 79$ anos), há tendência do período com menor esforço amostral apresentar maiores valores de média, o que aponta a necessidade da associação mais aprofundada dos dados utilizados com outras variáveis.

Se forem considerados os meses mais chuvosos (dezembro a março) de 2012 a 2014 e conhecendo-se o somatório das médias pluviométricas de dezembro a março para os 79 anos registrados - 876,8 mm, segundo o Daee (2016) -, verifica-se que o período de 2011/2012 apresentou somatório de 623,2 mm, 2012/2013 de 803,9 mm e 2013/2014 de 496,4mm. Segundo o histórico pluviométrico do Daee (2016), são somatórios pluviométricos inferiores ao somatório das médias de 1937-2015, caracterizando verões mais secos. Ainda é possível verificar que o ano de 2012 sofreu precipitações acima da média de abril a novembro (816,6 x 634,1 mm), porém 2013 sofreu precipitações inferiores (535,6 × 634,1 mm), assim como $2014(455,7 \times 634,1 \mathrm{~mm})$, o que demonstra escassez de chuvas mais acentuada no outono, inverno e primavera de 2013 e 2014. Além disso, se forem considerados os meses de janeiro, fevereiro e março para 2015, verifica-se que ocorreram igualmente chuvas abaixo da média histórica (513,7 × 647,6 mm).

Dessa forma, a região da Cantareira sofre regularmente períodos mais chuvosos no verão e primavera com diminuição das precipitações no outono e na primavera, podendo haver maior ou menor volume de precipitação conforme os anos analisados. Porém, não é possível apontar que atualmente vive-se a "pior seca dos últimos 80 anos" e que a falta de chuvas foi imprevisível, pois não se verificam dados concretos recentes que apontem estiagem severa; houve sim, no início da década de 1940, condição nítida de escassez pluviométrica, caracterizando, portanto, um comportamento cuja variabilidade já era conhecida ou ao menos esperada nos dias atuais.

De fato, nesse quadro natural geográfico-climático, as precipitações eventualmente diminuem, e, embora essa redução não caracterize, na média, estiagem prolongada, pode significar anos "secos" no futuro, com consequências sensíveis para a população da GSP. Contudo, quanto à questão climática e sua associação com a menor disponibilidade hídrica, deve-se ressaltar que a análise das influências climáticas globais e mesoregionais e do histórico pluviométrico de posto do Daee localizado na Serra da Cantareira aponta a necessidade de se identificarem outros elementos para a compreensão da crise hídrica atual, pois os menores volumes de chuva não explicam totalmente a falta d'água para abastecimento público. 


\section{Referências}

BARROS, L. A. A. Uma história visual da construção do Sistema Cantareira. São Paulo: Editora do Autor, 2013.

CONSUMO DE ÀGUA CRESCE MAIS QUE PRODUÇÃO. Folha de S. Paulo (online), 3abr. 2014. Disponívelem: <http://acervo.folha.uol.com.br/fsp/2014/04/03>. Acesso em: 20 nov. 2015.

CONTI, J. B. O conceito de desertificação. Climep: Climatologia e Estudos da Paisagem, Rio Claro, v. 3, n. 2, p. 39-52, 2008.

A desertificação como forma de degradação ambiental no Brasil. In: RIBEIRO, W. C. (Org.). Patrimônio ambiental brasileiro. São Paulo: Edusp/Imprensa Oficial, 2003. p. 167-187.

CÔRTES, P. L.; TORRENTE, M. Crise de abastecimento de água em São Paulo e falta de planejamento estratégico. Estudos Avançados, v. 29, n. 84, p. 7-26, 2015.

DAEE. DEPARTAMENTO DE ÁGUAS E ENERGIA ELÉTRICA. Banco de Dados Hidrológicos. São Paulo: Daee, 2016. Disponível em: <http://www.hidrologia. daee.sp.gov.br/Default.aspx?dadosorigem=Pluviom\%C3\%A9tricosEugrhi=UG RHIEcidadeugrhi=PIRACICABA\%2FCAPIVARI\%2FJUNDIAIE prefixoposto =D3-018>. Acesso em: 3 fev. 2016.

EMPLASA. Indicadores da Região Metropolitana de São Paulo. São Paulo: Emplasa, 2015. Disponível em: <http://www.emplasa.sp.gov.br/Emplasa/Indicadores/gsp.asp.> Acesso em: 20 nov. 2015.

FAGNANI, E. A lógica invertida da mercantilização. Entrevista em maio de 2015, concedida a C. Orsi. Jornal da Unicamp, Unicamp, Campinas, 2015.

FOLHA DE S. PAULO. Acervo online, dez. 2014/abr. 2015. Disponível em: <http:// search.folha.uol.com.br/>. Acesso em: 3 fev. 2016.

GARREAUD, R. D.; BATTISTI, D. S. Interannual (ENSO) and interdecadal (ENSOlike) variability in the Southern Hemisphere tropospheric circulation. Journal of Climate, American Meteorological Society Journals Online, v. 12, n. 7, p. 21132133, 1999.

GIROLDO, L. Terracetes de pisoteio de gado e mudanças morfo-pedológicas em vertente amostral na bacia hidrográfica do rio Jacareí, Serra da Mantiqueira-SP. Dissertação (Mestrado em Geografia Física) - Faculdade de Filosofia, Letras e Ciências Humanas, Universidade de São Paulo, São Paulo, 2013.

HISTÓRIA DOS RESERVATÓRIOS DE SÃO PAULO. Folha de S.Paulo (online), 8 fev. 2015. Disponível em: <http://wwwl.folha.uol.com.br/ infograficos/2015/02/118661-historia-dos-reservatorios-de-sao-paulo.shtml>. Acesso em: 20 nov. 2015.

INMET. INSTITUTO NACIONAL DE METEOROLOGIA. Sistema Nacional de 
Informações Hidro-Meteorológicas - SIM. Brasília: Inmet, 2016. Disponível em: <http://www.inmet.gov.br/projetos/rede/pesquisa/form_mapas_mensal. php>. Acesso em: 27 jan. 2016.

. Nota meteorológica especial: janeiro de 2014 é o mês recorde de calor na capital. São Paulo: Inmet, 70 Distrito, 2014.

ISA. INSTITUTO SOCIOAMBIENTAL. Cantareira 2006: um olhar sobre o maior manancial de água da Região Metropolitana de São Paulo. São Paulo: ISA, 2007.

JACOBI, R. J.; CIBIM, J.; LEÃO, R. S. Crise hídrica na macrometrópole paulista e respostas da sociedade civil. Estudos Avançados, v. 29, n. 84, p. 27-42, 2015.

MAESTU, J. Levantamento morfo-sedimentológico em planície fluvial meândrica: contribuição ao estudo dos geoindicadores. Trabalho de Conclusão de Curso (Graduação em Geografia) - Faculdade de Filosofia, Letras e Ciências Humanas, Universidade de São Paulo, São Paulo, 2008.

MORAIS, M. A.; CASTRO, W. A. C.; TUNDISI, J. G. Climatologia de frentes frias sobre a Região Metropolitana de São Paulo (RMSP) e sua influência na limnologia dos reservatórios de abastecimento de água. Revista Brasileira de Meteorologia, v. 25, n. 2, p. 205-217, 2010.

NEDER, R. T. Rede sociotécnica e inovação social para sustentabilidade das águas urbanas. São Paulo: Maluhy \& Co, 2008.

NUNES, L. H.; VICENTE, A. K.; CANDIDO, D. H. Clima da região Sudeste do Brasil. In: IRACEMA, F. A. C. et al. (Org.). Tempo e clima no Brasil. São Paulo: Oficina de Textos, 2009. p. 243-258.

PEREIRA FILHO, A. J. O aquecimento global não é o vilão da crise hídrica de São Paulo. Veja Ciência, São Paulo, 8 fev. 2015. Disponível em: <http://veja.abril.com. $\mathrm{br} /$ noticia/ciencia/o-aquecimento-global-nao-e-o-vilao-da-crise-hidrica-de-sao-paulo>. Acesso em: $16 \mathrm{dez} .2015$.

PRADO, L. F. Oscilação interdecadal do Pacífico e seus impactos no regime de precipitação no Estado de São Paulo. Dissertação (Mestrado em Meteorologia) - Instituto de Astronomia, Geofísica e Ciências Atmosféricas, Universidade de São Paulo, São Paulo, 2010.

RIBEIRO, W. C. Geografia política da água. São Paulo: Annablume, 2008.

. A ordem ambiental internacional. São Paulo: Contexto Acadêmica, 2001.

RODRIGUES, C. Atributos ambientais no ordenamento territorial urbano: o exemplo das planícies fluviais na metrópole de São Paulo. Geousp - Espaço e Tempo (online), v. 19, n. 2, p. 325-348, 2015.

Avaliação do impacto humano da urbanização em sistemas hidrogeomorfológicos: desenvolvimento e aplicação de metodologia na Grande São Paulo. Revista do Departamento de Geografia USP, v. 20, p. 111-125, 2010. 
A urbanização da metrópole sob a perspectiva da geomorfologia: tributo a leituras geográficas. In: CARLOS, A. F. A.; OLIVEIRA, A. U. D. (Org.). Geografias de São

Paulo: representação e crise da metrópole. São Paulo: Contexto, 2004. p. 89-114.

SANTOS, C. A. C. et al. Variability of extreme climate indices at Rio Claro, São Paulo,

Brazil. Revista Brasileira de Meteorologia, v. 27, n. 4, p. 395-400, 2012.

SÃO PAULO (Estado). Decreto n. 51.536, de 1 de fevereiro de 2007. Acrescenta funções ao campo funcional da Secretaria do Meio Ambiente, dispõe sobre as unidades transferidas para essa Pasta pelo inciso IV do artigo $2^{\circ}$ do Decreto no 51.460, de $1 \circ$ de janeiro de 2007, e dá providências correlatas. Disponível em: <>. Acesso em: 3 fev. 2016.

Lei n. 11.364, de 28 de março de 2003. Altera a denominação da Secretaria de Estado de Recursos Hídricos, Saneamento e Obras, autoriza o Poder Executivo a extinguir a Secretaria de Estado de Energia e dá providências correlatas. Disponível em: <http:// www.comitepcj.sp.gov.br/download/Lei-11364-03.pdf>. Acesso em: 3 fev. 2016.

. Lei n. 7.663, de 30 de dezembro de 1991. Estabelece normas de orientação à política estadual de recursos hídricos bem como ao sistema integrado de gerenciamento de recursos hídricos. Disponível em: <http://www.cetesb.sp.gov.br/licenciamento/documentos/1991_Lei_Est_7663.pdf>. Acesso em: 3 fev. 2016.

SCHRODER, R. Relatório sobre o estado atual do conhecimento da climatologia agrícola na região da bacia Paraná-Uruguai e plano de organização de um serviço agroclimatológico na mesma zona. São Paulo: Comissão Interestadual da Bacia Paraná-Uruguai, 1956.

SILVA DIAS, M. A. F. et al. Changes in extreme daily rainfall for São Paulo, Brazil. Climatic Change, v. 116, n. 3, p. 705-722, 2013.

SRTM. SHUTTLE RADAR TOPOGRAPHY MISSION. South America Images. Nasa, 2000. Disponível em: <http://www2.jpl.nasa.gov/srtm/southAmerica. htm>. Acesso em: 3 jul. 2009.

TARIFA, J. R.; ARMANI, G. Os climas "naturais". In: TARIFA, J. R.; AZEVEDO, T. R. (Org.). Os climas na cidade de São Paulo: teoria e prática. São Paulo: FFLCHUSP, 2001. p. 34-46.

TEIXEIRA, M. S.; SATYAMURTY, P. Dynamical and Synoptic Characteristics of Heavy Rainfall Episodes in Southern Brazil. Monthly Weather Review, v. 135, p. 598-617, 2007.

TRENBERTH, K. E. The definition of El Niño. Bulletin of the American Meteorological Society, v. 78, n. 12, p. 2771-2777, 1997.

WHATELY, M. A crise da água em São Paulo virou questão de fé. Notícias Socioambientais, 2004. Disponível em: <http://site-antigo.socioambiental.org/nsa/ detalhe? id $=1563>$. Acesso em: 26 fev. 2016.

ZUFFO, A. C. A hora de um novo marco regulatório. Entrevista em maio de 2015, concedida a C. Orsi. Jornal da Unicamp, Unicamp, Campinas, 2015. 